DOI: https://doi.org/10.32839/2304-5809/2020-78.1-24

UDC 81'373.611

Salata Iryna

Kryvyi Rih State Pedagogical University

\title{
TENDENCIES IN USING FEMINITIVES IN MODERN ENGLISH, UKRAINIAN, AND RUSSIAN. DIFFICULTIES IN TRANSLATION
}

Summary. This article is devoted to the study of tendencies of using feminitives in contemporary English, Ukrainian, and Russian. These tendencies are conditioned by different historical development of the languages under investigation and opposite approaches to the use of gender-specific nouns of feminine gender in these languages. The author mentions the factors that influenced on appearance of a new branch of linguistics gender linguistics, and speaks about the main spheres of usage (TV, Internet) of newly-formed feminitives in Ukrainian and Russian. The researcher also pays attention to the situation with the rules of forming feminitives in the Ukrainian and Russian languages, also touches upon the difficulties of appropriate translation of feminitives from and to the three analyzed languages.

Keywords: tendencies of using feminitives, gender linguistics, difficulties of translation of feminitives.

Салата I.A.

Криворізький державний педагогічний університет

\section{ТЕНДЕНЦЇ̈ ВИКОРИСТАННЯ ФЕМІНІТИВІВ В СУЧАСНІЙ АНГЛІЙСЬКІЙ, УКРАЇНСЬКІЙ ТА РОСІЙСЬКІЙ МОВАХ. ТРУДНОЩІ ПЕРЕКЛАДУ}

Анотація. Стаття присвячена вивченню тенденцій використання фемінітивів у сучасних англійській, українській та російській мовах. Ці тенденції зумовлені різним історичним розвитком досліджуваних мов та протилежними підходами щодо використання гендерно-маркованих слів жіночого роду. На сучасному етапі фрункціонування національних мов спостерігаються різні підходи до використання гендерно-маркованих слів, які є прямо протилежними у мовах, які ми досліджуемо. Відповідно до рекомендацій, прийнятих міжнародною організащією UNESCO в 1999 р. стосовно англійської мови, пропонуеться замість слів з суфіксами жіночого роду використовувати гендерно нейтральні слова на кшталт: poetess => poet, steward/stewardess => flight attendant, pl. cabin crew; запобігати використанню слів з гендерним маркером, зокрема woman doctor, policewoman та використовувати замість них нейтральні doctor та police officer. Також пропонується замінити частину складних слів -man на гендерно нейтральну -person та -people у множині. Наприклад, замість spokesman вживати spokesperson або spokespeople. Російська та українська мови рухаються у протилежному напрямку. На сучасному етапі відбувається активний процес утворення слів жіночого роду, тобто фемінітивів, від відповідних слів чоловічого роду. У статті згадуються найбільш поширені сфери використання «нових» фемінітивів, тобто створених в українській мові відповідно до нової редакції українського правопису, прийнятого в 2019 р., який регулюе правила утворення «нових» фемінітивів. Авторка також наводить декілька прикладів перекладу гендерно нейтральних слів з англійської мови українською та згадуе про труднощі прямого та зворотного перекладу фемінітивів досліджуваних мов через відсутність відповідних слів у сучасних словниках. Тому перекладачам слід приділяти більше уваги гендерному аспектові при перекладі та використовувати конструкції, які не утворюють гендерної асиметрії стосовно жінок в англійській мові, також знаходити варіанти слів, які повною мірою передаватимуть відповідні українські фемінітиви.

Ключові слова: тенденції використання фемінітивів, гендерна лінгвістика, труднощі перекладу фемінітивів.

Droblem statement. In the end of the XX century a new direction in contemporary linguistics appeared - gender linguistics. The push to the appearance of a new linguistic category gender and then to the independent linguistic branch became social factors, and the main one is the boosting of the feminist movement. In contemporary linguistics a gender aspect produced a lot of linguistic research works investigating ways, means and communicative situations of expressing gender in the language and speech.

Recent research and publications. According to A.V. Kirilina, the essence of the notion gender - a part of the model of a modern person reproducing in the language and speech sociocultural manifestation of sex - is not actually a linguistic category and may be represented through the analysis of the language structure [4].

In feminist linguistics two directions have been marked out: the investigation of the language for eliciting gender asymmetry and speech behaviour of men and women. Asymmetry directed against women is called language sexism. A research of feminist linguistics is guided by the hypothesis of Sapir-Whorf who claimed that a language is not only the means of communication in a society but it also participates in forming the way of thinking in a society. That's why all people being the bearers of a "man's" language live in a "man's" world picture.

The purpose of the article. The article is aimed at studying tendencies in the use of feminitives in modern English, Ukrainian, and Russian and ways of adequate translation of gender-specific nouns of feminine gender in these languages.

Presentation of the main material. Since the 1980s representatives of feminist linguistics have proposed recommendations on eliminating gender asymmetry in the English language. In 1999 UNESCO issued Guidelines on Gender-Neutral Language in which it is recommended to use gender-neutral words instead of words with suffixes of feminine gender: poetess - poet, steward/stewardess - flight attendant, pl. cabin crew [11, p. 13-14]; to avoid gender markers like woman doctor - doctor or to use them only if it is necessary in a concrete context [11, p. 12]. 
In Guidelines on Gender-Neutral Language Oxford Dictionary calls to change the part of the word man in compounds on gender-neutral - person (pl. people) or any other alternative gender-neutral variants: barman - bar tender - bar tenders, instead of spokesman to use spokesperson-( $\mathrm{pl}$. - spokespeople). Moreover, a word man in reference to any person is recommended to be changed to human being [6].

As for the Ukrainian and Russian languages, they are developing in quite opposite direction in comparison with English. During recent years the tendency to create and use more and more feminitives in both languages is being clearly traced. The most intensive usage of feminitives takes place in mass media - newspaper articles, TV news, talk shows, and Internet.

The Internet as means of communication is becoming a new sociocultural environment where development of communicators' personalities and their professional formation are going on. Among the most widely-spread forms of internet-communication are blogs, social nets, and forums on various themes, which contribute to the development of a special kind of communication - Internet discourse.

The study of Internet as a universal means of communication shows that a lot of new words including also feminitives were firstly introduced in the Internet language as if to "test" them and see how the society will react: either reject or take them into everyday usage.

Nowadays in the Russian language segment of social nets we can meet a lot of groups devoted not only to the problems of feminism but also to the use and creation of feminitives, more than that, a lot of internet resources are being created, for example: http://feminism-russia.ru/feminizator and others, which help to check the correctness of a feminitive and even create your own one [9]. Besides, there is a web-site - dictionary of gender terms devoted to the terminology in the spheres of feminism and gender - http://a-z-gender.net/ feminitivy.html [7]. Hot discussions are going on http://envrm.github.io/apps/feminizator/feminizator. html on how it is correct to say in Russian теологиня or теологесса, фбилологиня or фбилоложка; if the words политикиня, знатокиня, авторка coincide with the norms of the Russian language [14].

In Russian there are still no words of feminine gender for all nominations in the language. Only 50\% of analysed nominations referring to women are feminitives. More than that, a lot of spheres of activities in the language are still considered "man's", despite the fact that nowadays women take an active part in these spheres, for example, how to say in Russian about a woman инженер оr врач or доктор.

In contrast to the situation in the Russian language which still does not have the written rules that regulate the formation of new feminitives, in Ukraine in 2019 a new reduction of the Ukrainian spelling was adopted. According to the new rules of spelling the feminitives in the Ukrainian language are formed by means of a number of suffixes such as: - $\kappa^{-},-u u_{-},-e c,-u \psi_{-}$, for example: 1$)-\kappa^{-}$is the most productive as most of newly-created feminitives are formed with the help of this suffix авторка, міністерка, поліціянтка, доцентка, депутатка, прем'єрка; 2) -ии- (unproductive), such words as засновниия, підприелниия, переможниия have already functioned in the language and are fixed in the dictionaries of the modern Ukrainian language; 3) -ec- (international) - баронеса, критикеса, поетеса, актриса, the least productive suffix as there is a tendency to use now поетка instead of поетеса, акторка instead of aктриса); 4) -ин- becoming more productive nowadays, as alongside with the so called "old" words - княгиня, графбня, кравчиня, майстриня, new feminitives are being produced - мисткиня, виборчиня, ббахівчиня, шефбиня, членкиня, ворогиня, ббілологиня, фботографбиня.

Having compared these three languages we would like to conclude that in any language under investigation a phenomenon, which is analyzed, has different historical development and quite opposite representation on the contemporary stage of these languages functioning. The English language is proceeding the way of neutralization gender markers, to some extent due to the absence of grammatical category of gender. In the Russian and Ukrainian languages we observe the ongoing process of feminization on different stages.

Taking into consideration everything mentioned above, we have analyzed a number of internet news to find the appropriate English translation of some Ukrainian feminitives (we did not investigate "new" Russian feminitives as such that still do not have written norms adopted in the language) and found out the state of affairs like the following.

The BBC news "A Dallas, Texas police officer made a mistake in the apartment and shot the man, thinking he had run into her home" is translated as „Співробітниия поліцї̈ в Далласі, штат Техас, полилилася квартирою $і$ застрелила чоловіка, думаючи, що він вдерся до неї додому" [13]. So we see a discrepancy between an English gender-unmarked word police officer and its Ukrainian translation, a word of feminine gender співробітниия.

Doctor of philological sciences O. Ponomariv, who has had his blog on the BBC since 2009, answering a reader's question "Which word is better to use in Ukrainian посолка or послиня?" offers not to use any of them, better saying пані посол. But if we address any of the on-line Ukrainian-English or English-Ukrainian translation services the only variant of translation is Mrs. Ambassador [2].

As for Ukrainian feminitives newly created according to a new reduction of the Ukrainian spelling, such words as політикиня, знатокиня, авторка, членкиня, міністерша, поліціянтка, доцентка, etc. have not had yet their analogies even in on-line Ukrainian-English dictionaries, saying nothing about their paper versions. But it is only the matter of time. I hope, soon we'll have new dictionaries including all new words created according to a new reduction of the Ukrainian spelling and their politically correct translation taking into account the rules of each language.

Conclusion. To sum up our research, we'd like to emphasize that now translators from Russian and Ukrainian into English and vice versa should pay more attention to the gender aspect of translation, to which not so much significance has not been attached recently, and try to choose constructions not creating gender asymmetry in case of speaking about women in the English language and corresponding words that fully transmit the meaning of Russian and Ukrainian feminitives. 


\section{References:}

1. Belovolchenko H. Shcho take feminityvy i yak yikh utvoriuvaty. URL: https:/section.in.ua/erudition/feminities/ (accessed: 05.02.2020).

2. Bloh profesora Ponomariva. URL: https://www.bbc.co.uk/blogs/ukrainian/ponomariv/2011/05 (accessed: 05.02.2020).

3. Hender dlia medii. Pidruchnyk iz hendernoii teorii dlia zhurnalistyky ta inshykh sotsiohumanitarnykh spetsialnostei / za red. M. Maierchyk, O. Plakhotnik, H. Yarmanovoii. Kyiv: Krytyka, 2017. 221 p.

4. Kirilina A.V. (2004). Gendernye issledovaniya v lingvistike i teorii kommunikatsii: uchebnoe posobie dlya studentov vysshikh uchebnykh zavedenij [Gender Studies in Linguistics and Communication Theory: A Textbook for Students in Higher Educational Institutions]. Moskva: Rossijskaya politicheskaya ehnciklopediya (ROSSPEHN), 252 p. (in Russian)

5. Malakhova O. Feminityvy - ne danyna modi, vony vlastyvi ukraiinskii movi yak systemi. URL: https://womo.ua/ olena-malahova/ (accessed: 02.02.2020).

6. Oxford Dictionary. URL: https://www.oed.com/

7. Slovar gendernykh terminov. URL: http://a-z-gender.net/feminitivy.html (accessed: 05.02.2020).

8. Smoliar L. Try prychyny, chomu varto vzyvaty feminityvy. URL: https://life.pravda.com.ua/columns/2017/10/28/ 227141/ (accessed: 06.02.2020).

9. Feminizator - generator feminitiviv. URL: http://feminism-russia.ru/feminizator (accessed: 03.02.2020).

10. Epshtein M. Feminitivy - ili slova obshchego roda? Nuzhny li yazyku slova "avtorka" i "filosofinia"? URL: https://snob.ru/profile/27356/blog/133860 (accessed: 05.02.2020).

11. Guidelines on Gender-neutral Language. URL: https://www.un.org/en/gender-inclusive-language/guidelines.shtml

12. Saul, Jennifer, "Feminist Philosophy of Language", The Stanford Encyclopedia of Philosophy (Winter 2012 Edition), Edward N. Zalta (ed.). URL: https://plato.stanford.edu/archives/win2012/entries/feminism-language/

13. U SShA (the USA) politsiiantka zastrelyla cholovika v yoho kvartyri, dumaiuchy, shcho vona u sebe vdoma. URL: https://www.bbc.com/ukrainian/news- 45452818

14. Barbikop: ekskliuzyvne interviu z naividomishoiu politsiiankoiu krainy (video). URL:https://antikor.com.ua/ articles/51202barbikop_ekskljuzivne_intervju_z_najvidomishoju_politsijantkoju_krajini_video

15. Perevodchik s ukrainskogo na angliiskii. URL: https://perevod.i.ua/ukrainsko-angliyskiy/

16. Perevodchik onlain. URL: http://translate.meta.ua/

17. Perevodchik s ukrainskogo na angliiskii. URL: https://pereklad.online.ua/ukrainsko-angliyskiy/

\section{Список літератури:}

1. Беловольченко Г. Що таке фемінітиви і як їх утворювати. URL: https://section.in.ua/erudition/feminities/ (дата звернення: 05.02.2020).

2. Блог професора Пономаріва. URL: https://www.bbc.co.uk/blogs/ukrainian/ponomariv/2011/05 (дата звернення: 05.02.2020).

3. Гендер для медій. Підручник із гендерної теорії для журналістики та інших соціогуманітарних спеціальностей / за ред. М. Маєрчик, О. Плахотнік, Г. Ярманової. Київ : Критика, 2017. 221 с.

4. Кирилина А. В. Гендерные исследования в лингвистике и теории коммуникации: учебное пособие для студентов высших учебных заведений. Москва : Российская политическая энциклопедия (РОССПЭН), 2004. 252 с.

5. Малахова О. Фемінітиви - не данина моді, вони властиві українській мові як системі. URL: https://womo.ua/ olena-malahova/ (дата звернення: 02.02.2020).

6. Oxford Dictionary. URL: https://www.oed.com/

7. Словник гендерних термінів. URL: http://a-z-gender.net/ua/feminitivi.html (дата звернення: 05.02.2020).

8. Смоляр Л. Три причини, чому варто вживати фемінітиви. URL: https://life.pravda.com.ua/columns/2017/10/28/ 227141/ (дата звернення: 06.02.2020).

9. Феминизатор-генератор феминитивов. URL: http://feminism-russia.ru/feminizator (дата звернення: 03.02.2020).

10. Эпштейн М. Феминитивы или слова общего рода? Нужны ли языку слова «авторка» и «рилософиня»? URL: https://snob.ru/profile/27356/blog/133860 (дата обращения: 05.02.2020).

11. Guidelines on Gender-neutral Language. URL: https://www.un.org/en/gender-inclusive-language/guidelines.shtml

12. Saul, Jennifer, "Feminist Philosophy of Language", The Stanford Encyclopedia of Philosophy (Winter 2012 Edition), Edward N. Zalta (ed.). URL: https://plato.stanford.edu/archives/win2012/entries/feminism-language/

13. У США поліціянтка застрелила чоловіка в його квартирі, думаючи, що вона у себе вдома. URL: https://www.bbc.com/ukrainian/news-45452818

14. Барбікоп: ексклюзивне інтерв’ю з найвідомішою поліціянткою країни (відео). URL:https://antikor.com.ua/ articles/51202barbikop_ekskljuzivne_intervju_z_najvidomishoju_politsijantkoju_krajini_video

15. Переводчик с украинского на английский. URL: https://perevod.i.ua/ukrainsko-angliyskiy/

16. Переводчик онлайн. URL: http://translate.meta.ua/

17. Переводчик с украинского на английский. URL: https://pereklad.online.ua/ukrainsko-angliyskiy/ 